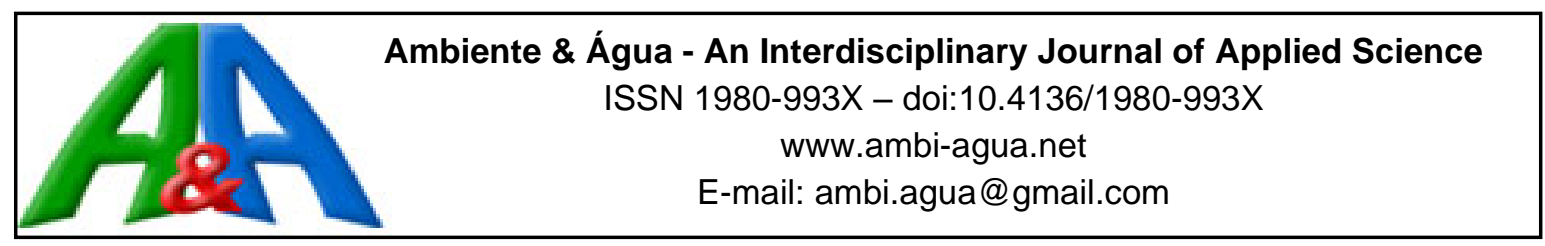

\title{
Application of a simplified methodology for classification of small dams in cascade
}

\author{
ARTICLES doi:10.4136/ambi-agua.2790
}

Received: 10 Sep. 2021; Accepted: 05 Jan. 2022

\section{Daniel Andrioli de Lima1 ${ }^{(\mathbb{D})}$; Guilherme Theodoro Nascimento Pereira de Lima ${ }^{2}$; Vitor Eduardo Molina Júnior ${ }^{1}{ }^{D}$; Laura Maria Canno Ferreira Fais ${ }^{1 *}$ \\ ${ }^{1}$ Faculdade de Tecnologia. Universidade Estadual de Campinas (UNICAMP), Rua Paschoal Marmo, ${ }^{\circ} 1888$, CEP: 13484-332, Limeira, SP, Brazil. E-mail: d149861@g.unicamp.br, vemolina@unicamp.br \\ ${ }^{2}$ Departamento de Planejamento, Gestão e Finanças da Unidade de Gestão de Planejamento Urbano e Meio Ambiente (DPGF/UGPUMA). Prefeitura Municipal de Jundiaí, Avenida da Liberdade, s/n, CEP: 13214-900, Jundiai, SP, Brazil. E-mail: gtnplima@gmail.com \\ *Corresponding author. E-mail: lauramf@unicamp.br}

\begin{abstract}
Dams pose a high potential risk due to the possibility of rupture. An accident can cause severe consequences for the economy and the environment, besides the loss of human lives. In addition to large dams for power generation, there are also a large number of small earth dams throughout the world, mainly in rural areas, built for the purpose of irrigation or watering animals. Problems with small dams are also frequent, especially in periods of high rainfall when they are more prone to failure. When dams are in cascade, the probability of a rupture is even greater than with an isolated dam, since in most cases small dams do not have enough freeboard to contain the volume coming from the dam further upstream. However, Brazilian legislation relating to water dams only covers the large ones, unless they are classified with high Hazard Potential (DPA for its acronym in Portuguese). Thus, there is no specific legislation for small dams, which means that many of them do not undergo regular inspections and proper safety assessment. This work aims to apply the simplified classification developed by the National Laboratory of Civil Engineering (LNEC for its acronym in Portuguese) for dams in cascade and to compare it to the classification of the Brazilian law for the DPA, evaluating its applicability for small dams. In this way, this method will complement and facilitate decision-making by owners and regulators, thus allowing special attention to the safety of small dams all over the world.
\end{abstract}

Keywords: dams in cascade, dams safety, small earth dams.

\section{Aplicação da metodologia simplificada de classificação de pequenas barragens em cascata}

\section{RESUMO}

Barragens são elementos com alto potencial de risco devido à probabilidade de ruptura. Um acidente pode causar graves consequências para a economia, para o meio ambiente, além da perda de vidas humanas. Além das grandes barragens para geração de energia, existe também um grande número de pequenas barragens de terra no mundo, principalmente em áreas rurais, construídas com a finalidade de irrigação ou dessedentação de animais. Os problemas com 
pequenas barragens também são frequentes, especialmente em períodos de muita chuva, quando estão mais sujeitos a rompimento. Quando as barragens estão em cascata, a probabilidade de seu rompimento é ainda maior do que quando há barragem isolada, pois, na maioria dos casos, as pequenas barragens não possuem borda livre suficiente para conter o volume proveniente da barragem mais a montante. Porém, no Brasil, para barragens de água, a legislação abrange apenas as grandes, a menos que sejam classificadas com alto Dano Potencial Associado (DPA). Assim, não existe uma legislação específica para pequenas barragens, o que significa que muitas delas não passam por inspeções regulares e avaliações de segurança adequadas. Este trabalho visa aplicar a classificação simplificada desenvolvida pelo Laboratório de Engenharia Civil de Portugal (LNEC) para barragens em cascata e compará-la com a classificação da lei brasileira para a DPA, avaliando a sua aplicabilidade para pequenas barragens. Desta forma, este método de classificação poderá complementar e facilitar a tomada de decisões por parte dos proprietários e reguladores, permitindo assim uma atenção especial à segurança das pequenas barragens em todo o mundo.

Palavras-chave: barragens em cascata, pequenas barragens de terra, segurança de barragens.

\section{INTRODUCTION}

Water is essential for life; man therefore occupies areas where this resource is available. Considering the increase in water demand over the time, and that its availability is not constant, the regularization of rivers through dams is necessary for the maintenance of human development and the well-being of a society.

With agricultural development and a greater need for food, there has been an increase in the construction of small dams, especially in rural areas and in arid regions. They are used for irrigation, watering animals, and even to minimize problems with flooding, and substantially contribute to the socioeconomic development of small rural properties. They also have a potential to mitigate future climate change consequences. However, due to the lack of proper management by the owners, they can become a threat to the region where they are built (Bocchiola et al., 2014; Alahiane et al.,2016; Agoramoorthy et al., 2016; Hintze et al., 2016).

Despite some dams being small, they can cause risks to the population, as they are often built without an adequate project, technical responsibility or the authorization of the responsible regulatory agency. Thus, they also need inspections for proper monitoring of their behavior, requiring a joint action of regulatory agencies and owners for the safety management of these dams (Dam et al., 2012).

Accidents with large dams are reported around the world; on the other hand, occurrences with small dams located in rural areas are generally less reported, but more frequent, especially in developing countries. In the Czech Republic, there are approximately 20,000 small dams, many of which broke in rain events in 1997, 2002 and 2010; there were also occurrences in Tasmania, Australia, United States, Indonesia, among other countries, with dams less than 10m high. In Brazil, in the northeastern region, between 1887 and 1906, 129 small dams broke, in addition to other accidents in the states of Ceará and Pará (Pisaniello et al., 2011; 2015; Aguiar et al., 2015; К̌́ha et al., 2020; Nava et al., 2021).

The safety of a dam includes structural, geotechnical, hydraulic, operational and environmental aspects, besides the auscultation of important parameters. It is also worth mentioning that managing the safety of small dams must involve public authorities, owners and the community. (Pacheco et al., 2020; Lima et al., 2021).

Risk analysis tools, such as those developed by Kalinina et al. (2018), Li et al. (2019), He et al. (2020), can be used to evaluate the level of safety of a dam. Nevertheless, for Garcia et al. (2019), when considering small dams, indexes are more appropriate to provide general 
information regarding the structure, as they are less time and cost consuming. Pimenta et al. (2013), Sun et al. (2014), Zheng et al. (2015), Zhou et al. (2015), Jing et al. (2018), among others presented simpler tools that can be used to evaluate the level of safety of a dam.

Despite all the problems involving small dams, few countries (among them, Portugal can be mentioned) have specific legislation and/or recommendations for them. There is no specific data for risk assessment and classification purposes, making the small dams' safety assessment and management more difficult. Thus, it is important to have more specific tools for the small dams, considering their particularities, and that can be easily applied (Luccas et al., 2020; Lima et al., 2020).

In Brazil, Law $n^{\circ} 12.334 / 10$, amended by Law $n^{\circ} 14.066 / 20$, named Brazilian Policy of Dams Safety (BPDS), which addresses the accumulation of water for any uses, the final or temporary disposal of tailings and the accumulation of industrial waste (Brasil, 2020). However, only dams larger than $15 \mathrm{~m}$ height, or with reservoirs with a volume greater than $3 \cdot 10^{6}$ $\mathrm{m}^{3}$, are included in it, unless they have a medium/high Hazard Potential (DPA) classification. This classification does not meet small dams, which do not require regular safety inspections, increasing the risk of an accident.

Thus, this work applies the simplified methodology for cascading dams developed by the Brazilian Water and Sanitation Agency (ANA for its acronym in Portuguese) and the National Laboratory of Civil Engineering (LNEC for its acronym in Portuguese), in partnership with the World Bank, comparing it with the DPA classification according to Law $\mathrm{n}^{\circ} 12.334 / 10$.

Several authors have elaborated simplified methods for determining the parameters of the breach, the peak flow or the failure impact zone (España, 1996; Schaefer and Barker, 2007; Melo, 2015; Petry et al., 2018). However, the classification presented here is intended to make it clear to decision makers the danger of not observing the possible risks of cascading dams, especially the small earth dams in rural areas. The method is a previous analysis and its results show, in a simple and low-cost way, the areas that must be monitored.

\section{MATERIAL AND METHODS}

The municipality of Campinas, State of São Paulo, has an approximate area of $800 \mathrm{~km}^{2}$, being about $400 \mathrm{~km}^{2}$ of rural area. There are 358 dams in the municipality, 80 of them located in the Microbasin of Ribeirão das Cabras, which has environmental relevance for being in the Environmental Protection Area (APA) of Campinas. About $75 \%$ of these dams are used for irrigation/livestock (ANA, 2019; Campinas, 2016).

To carry out this research, 24 of these 80 dams were chosen; they are arranged in cascades, located in 4 private properties, (named here X1, X2, X3 and X4), as shown in Figures 1 and 2. The Institute of Technological Research (IPT, 2002) created a technical report, from which information was obtained about the dams, such as their length and height, geographic coordinates and, for some of them, the freeboard and the water surfaces (with normal and maximum water levels).

The assessment of the surroundings of the dams was made from an orthophoto from 2014, available at https://informacao-didc.campinas.sp.gov.br/metadados.php from the server http://wms2.campinas.sp.gov.br/wmsmap/wms_ortofoto_2014.map. The orthophoto is in a raster format, with GSD (Ground Sample Distance) resolution of $10 \mathrm{~cm}$, photo capture (aero photogrammetric coverage): July 2014, coordinate reference system: SIRGAS 2000 UTM 23 S. From this orthophoto it was possible to visualize existing elements, such as roads, buildings, and other features.

The DPA classification of the dam was based on Resolution $n^{\circ} 143 / 2012$ of the Brazilian Water Resources Council (CNRH for its acronym in Portuguese) (CNRH, 2012). According to this Resolution, scores are assigned to each one of the criteria that compose DPA, depending on the characteristics of the dam. The final grade is the sum of the scores for each criterion. 


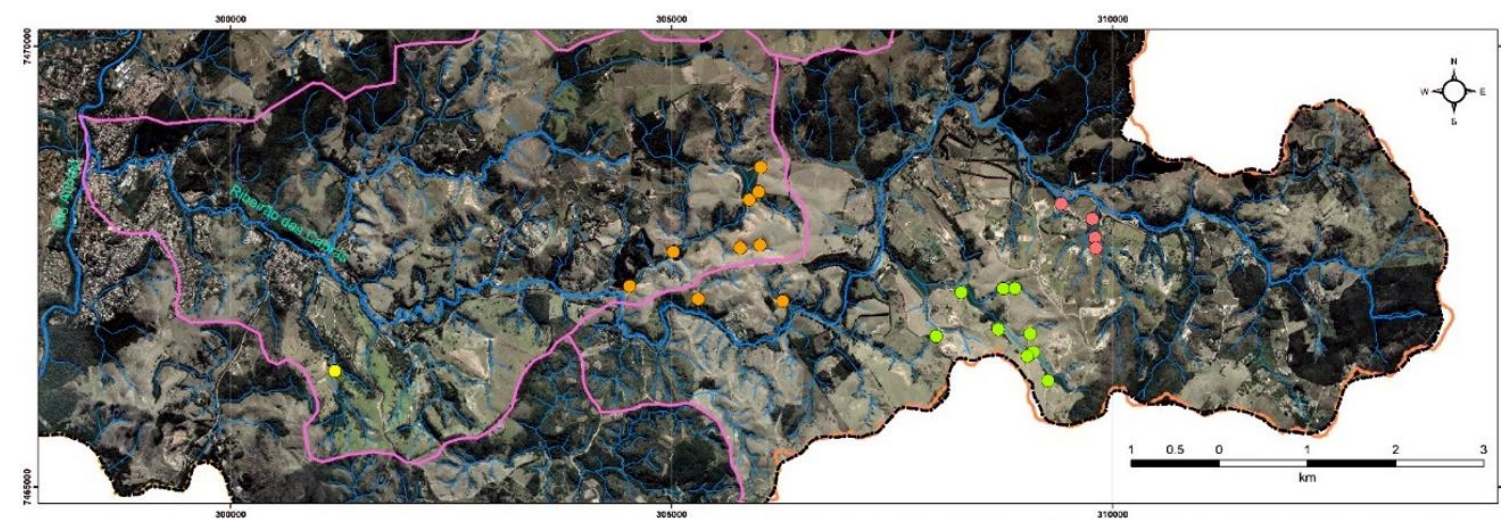

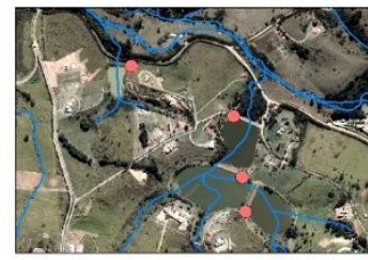

Property X1

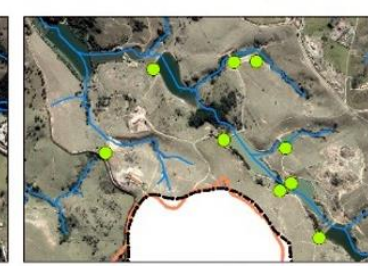

Property $X 2$

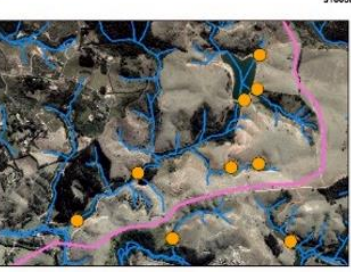

Property X3

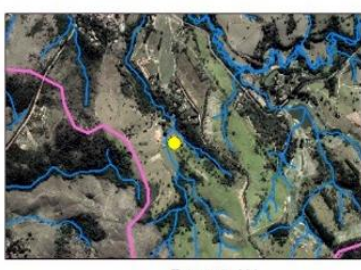

Property $\mathrm{X} 4$

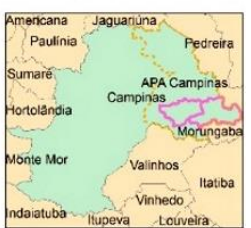

Figure 1. Location of the Ribeirão das Cabras Watershed and the 24 dams.
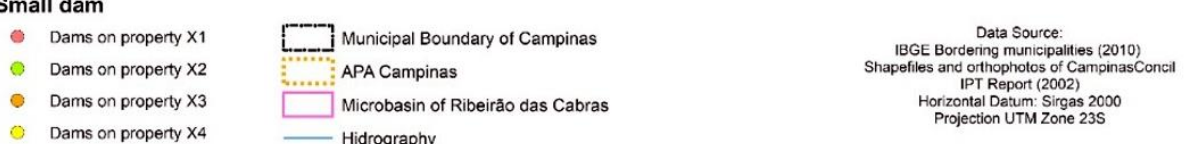

ndaiatuba - vimecas

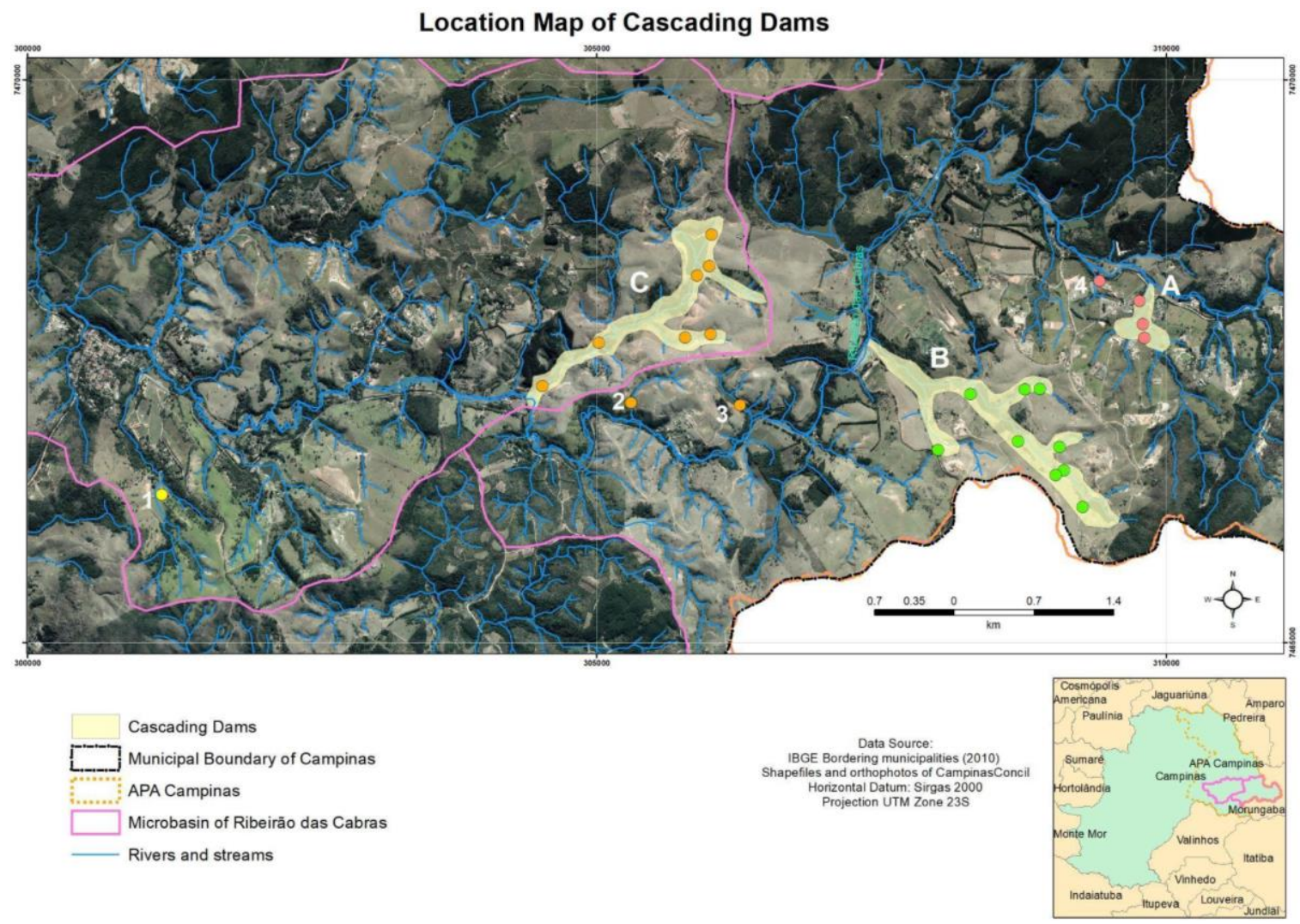

Figure 2. Location of cascading formations regions.

Then, the classification was made according to the simplified method for dams in cascade, proposed by LNEC in partnership with the World Bank (World Bank, 2014) and it was 
elaborated from practices recommended by (España, 1996; Schaefer and Barker, 2007).

The method consists in a simplified classification of the DPA of cascading dams, based on the premise that the spillway of a downstream dam will not be able to drain the flood of the failure of an upstream dam. Thus, if the free edge of the dam under analysis comprises all the influent volume, it will not fail; otherwise, it will break. The method follows the steps:

1. The DPA classification of isolated dams is carried out;

2. The further downstream dam keeps the isolated DPA isolated;

3. If the downstream dam does not store in its free edge the total influent volume due to the rupture of the upstream dam, it will break; so, to the upstream dam should be assigned the classification of highest DPA between both.

The ideal is having information about the free edge of the analyzed dams. If this information is not available, it is estimated, depending on the total volume of the dam, as follows: for a dam height up to $3 \mathrm{~m}$, the freeboard volume is $20 \%$ of the reservoir volume; for dams with a height between $3 \mathrm{~m}$ and $15 \mathrm{~m}$, the freeboard volume is $10 \%$ of the reservoir volume; dams with a height between $15 \mathrm{~m}$ and $60 \mathrm{~m}$, the freeboard volume is $50 \%$ of the reservoir volume (World Bank, 2014).

Based on the described method, one made the classification of the 24 dams in cascade.

\section{RESULTS AND DISCUSSION}

For the Hazard Potential (DPA for its acronym in Portuguese) classification, 20 dams were chosen, arranged in 3 cascades (named A, B and C), in addition to 4 isolated dams (which are not in cascade), thus totaling 24 dams, as shown in Figure 2.

Thus, the Hazard Potential classification was done for the 24 dams in isolation, and the simplified classification of LNEC was done for those ones in cascade.

\subsection{DPA Classification according the Brazilian Policy of Dams Safety}

From the information available about the dams, the DPA classification was made according to CNRH (2012). The criteria considered for this classification is presented in the Supplementary Material (Table 2), and it is worth remembering that all the dams are classified separately.

The dam named 1 (8.3m high) was the only one classified with high DPA, as it is located immediately upstream of an urban area, which increases the probability of loss of human life if it breaks. On the other hand, Dams 2 (7.8m high), 3 (no height information) and 4 (4.4m high) were classified as having low DPA.

The dams A1 to A3, B1 to B10 and C1 to C7, all have low DPA when they are classified in isolation, since downstream of them there are no buildings with permanent occupation. Thus, according to the Brazilian Law, these dams considered in isolation, would have no obligation of regular inspection by the regulatory agency, as already mentioned by Lima et al. (2021).

It is noteworthy that the attribution of scoring and evaluation of the categories does not totally eliminate the subjective character, as it is made from the observation of the dam's surroundings, with an interpretation that depends on the experience of the technician who will carry out the on-site inspection.

\subsection{Classification according to LNEC simplified methodology}

The simplified methodology of LNEC (described previously) was applied to classify the dams in cascade. Figure 3 presents the 3 cascades considered in this research, and their classification is presented in Table 1 . 

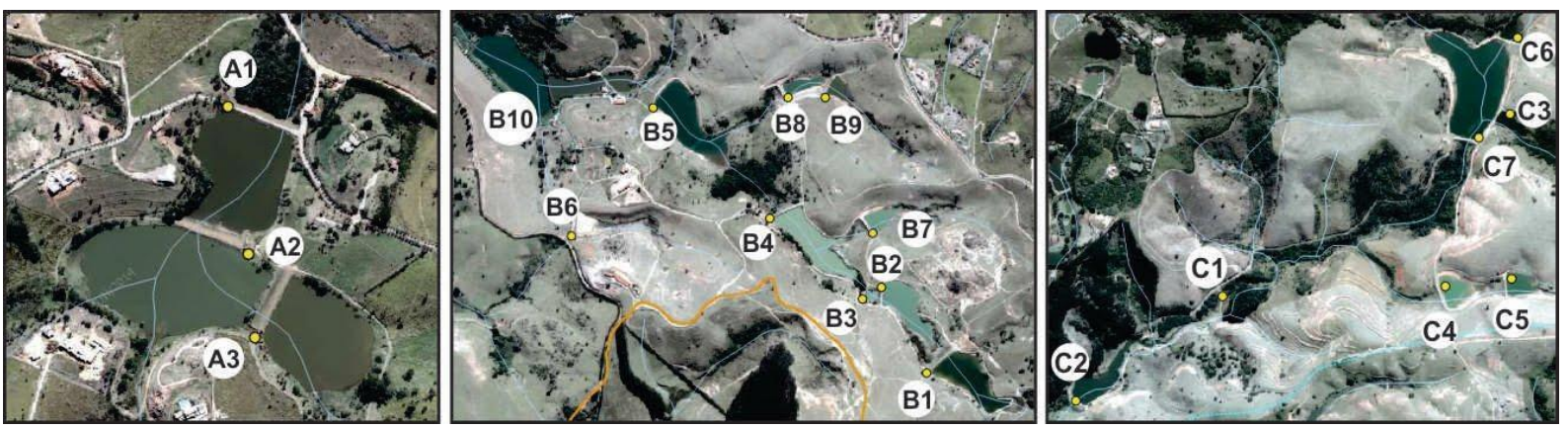

Figure 3. Cascade of regions $\mathrm{A}, \mathrm{B}$ and $\mathrm{C}$.

Table 1. Classification of Cascade Dams according to the simplified methodology.

\begin{tabular}{ccccc}
\hline Dam & Height $(\mathrm{m})$ & Volume $\left(\mathrm{m}^{3}\right)$ & Free Board Volume $\left(\mathrm{m}^{3}\right)$ & DPA Cascade \\
\hline A1 & 8 & 34,685 & 3,000 & Low \\
A2 & 8 & 53,672 & 5,000 & High \\
A3 & 8 & 15,127 & 2,000 & High \\
B10 & 6 & 63,241 & 6,000 & Low \\
B5 & 8 & 356,720 & 36,000 & High \\
B8 & 16.5 & 139,639 & 70,000 & High \\
B9 & 5.9 & 37,878 & 4,000 & Low \\
B6 & 6.2 & 57,939 & 6,000 & High \\
B4 & 9.2 & 277,840 & 28,000 & High \\
B7 & 6 & 44,664 & 4,000 & High \\
B3 & 6.9 & 18,036 & 2,000 & High \\
B2 & 7.4 & 151,463 & 15,000 & High \\
B1 & 7.6 & 251,864 & 25,000 & High \\
C2 & 7.5 & 114,637 & 11,000 & Low \\
C1 & 6 & 0 & 0 & Low \\
C4 & 11.5 & 232,737 & 23,000 & High \\
C5 & 11 & 92,719 & 9,000 & High \\
C7 & 18.5 & 761,626 & 381,000 & High \\
C3 & 5.3 & 24,104 & 2,000 & High \\
C6 & 6 & 30,498 & 3,000 & High \\
\hline
\end{tabular}

Dam "A1" is the most downstream in the cascade, so it keeps the low DPA, which is the same as the isolated classification. From there, the classification of the dams is carried out, evaluating whether the downstream dam would store on its freeboard the volume released if the immediately upstream dam failed. Thus, if the A2 breaks, A1 does not store the influent volume on its freeboard, and it would inherit the DPA. As it is already low, your DPA would change to medium, and the same procedure is done for the entire cascade.

For the B cascade, it is observed that the B10 and B9 dams would store on their freeboard their excess volume plus the volume of the B5 and B6. However, dams B8, B4, B7, B3, B2 and B1 do not have enough freeboard to store the excess volume, so they are classified with high DPA. With the failure of the more upstream dams and accumulation of all the flood, there is a great probability that the further downstream dams will also break, including those with low DPA.

Cascade $\mathrm{C}$ is composed of 7 small dams; $\mathrm{C} 2$ and $\mathrm{C} 1$ dams maintain the low DPA of the isolated classification, as they are further downstream, and the others would have a high DPA, according to the simplified method.

It is worth remembering that the simplified method considers the possibility that the volume released by a dam failure also breaks the dam immediately downstream (if the free edge 
of this one does not store the total influent volume). Thus, according to Schaefer and Barker (2007), if the failure of the upstream dam would cause the failure of the downstream one, then the classification for the upstream dam must be as high or higher than the downstream dam(s). That's why in some cases, the most upstream dams are classified with high DPA, while the more downstream dams are classified with low DPA.

Figure 4 shows the classification for the cascades, both separately (low DPA) and together (medium and high DPA).
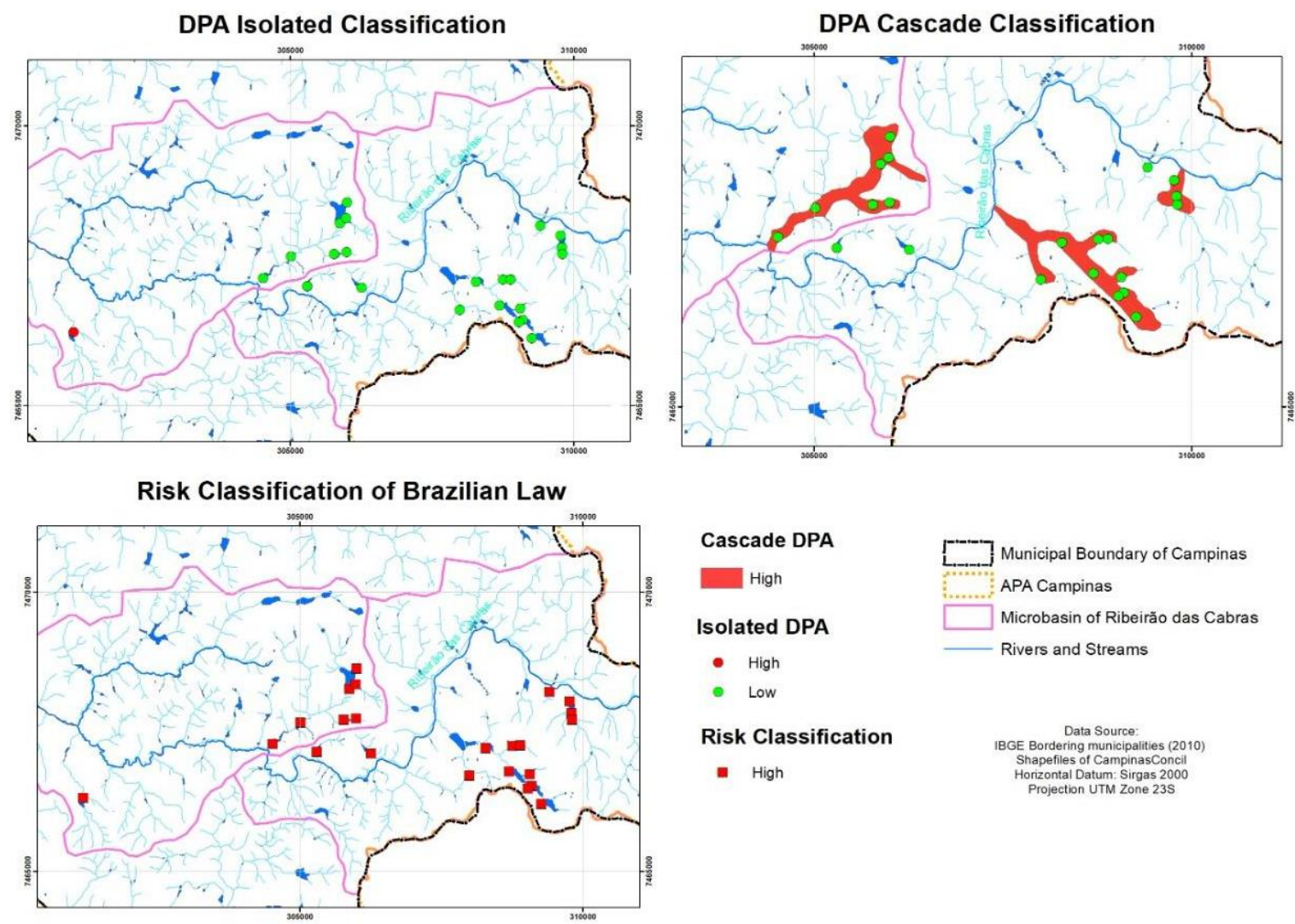

Figure 4. Classification of the small dams in cascade.

The method applied in this research is a simplified one, and it is important to a previous safety assessment of the dam. Besides, results show that attention needs to be paid to small dams, especially when they are cascades.

\section{CONCLUSIONS}

Dams are important structures for the development and well-being of a society. In small rural properties, it is common to build small dams for irrigation, animal watering, or other purposes. Although less reported, accidents with small dams are frequent, and few countries have specific legislation or criteria for evaluating the safety of these structures.

In this study, the DPA evaluation of small dams was carried out based on the criteria defined in the Brazilian legislation and from a simplified classification for cascading dams, proposed by LNEC.

It is worth remembering that both methods applied to small dams proved to be useful for an assessment of the Hazard Potential, and to delimit risk areas around the dams. Besides, the results presented here highlight that a dam can be classified as low DPA when isolated (therefore, without the inspections imposed by Brazilian law) but can change to high DPA when the analysis is done in cascade. Attention must therefore be paid to small dams, especially when they are in cascade. 
Another important issue is that small dams have their own characteristics, which make them different from large ones. Often, compliance with legislation to guarantee the safety of the structure could make economic activities unfeasible for small owners, since, unlike large dams, the small ones are generally not built for profit and/or generate large incomes for the owner. Therefore, they need specific criteria of classification and special attention when comparing them to the large dams.

The results presented here can be used in a simple, direct and low-cost way for readjustment and regularization of small dams, ranking them in terms of their criticality. Finally, it is worth remembering that it is necessary for joint actions by the owner, public authorities and the community to guarantee the safety of these structures and their surroundings.

\section{ACKNOWLEDGEMENTS}

This study was financed in part by the Coordenação de Aperfeiçoamento de Pessoal de Nível Superior - Brasil (CAPES) - Finance Code 001.

\section{REFERENCES}

AGÊNCIA NACIONAL DE ÁGUAS (Brasil). Classificação de Barragens. Brasília, 2019. Available: https://capacitacao.ana.gov.br/conhecerh/handle/ana/477 Access: 25 July 2019.

AGORAMOORTHY, G.; CHAUDHARY, S.; CHINNASAMY, P.; HSU, M. J. Harvesting river water through small dams promotes positive environmental impact. Environmental Monitoring and Assessment, v. 188, p. 645, 2016. https://doi.org/10.1007/s10661-016$5640-5$

AGUIAR, D. P. O.; FAIS, L. M. C. F.; GENOVEZ, A. I. B.; FILHO, J. G. D. Contribuição ao estudo do índice de segurança de barragens - isb. Revista Brasileira de Recursos Hídricos, v. 20, n. 2, p. 360 - 368, 2015.

ALAHIANE, N.; ELMOUDEN, A.; AITLHAJ, A.; BOUTALEB, S. Small dam reservoir siltation in the Atlas Mountains of Central Morocco: analysis of factors impacting sediment yield. Environmental Earth Science, v. 75, p. 1035, 2016. https://doi.org/10.1007/s12665-016-5795-y

BOCCHIOLA, D.; ROSSO, R. Safety of Italian dams in the face of flood hazard. Advances in $\begin{array}{llllll}\text { Water Resources, } & \text { n. } & \text { 71, } & \text { p. } & \text { 23-31, }\end{array}$ https://doi.org/10.1016/j.advwatres.2014.05.006

BRASIL. Presidência da República. Lei n. 14.066, de 30 de setembro de 2020. Altera a Lei no 12.334, de 20 de setembro de 2010, que estabelece a Política Nacional de Segurança de Barragens (PNSB), a Lei n ${ }^{\circ}$ 7.797, de 10 de julho de 1989, que cria o Fundo Nacional do Meio Ambiente (FNMA), a Lei ${ }^{\circ}$ 9.433, de 8 de janeiro de 1997, que institui a Política Nacional de Recursos Hídricos, e o Decreto-Lei no 227, de 28 de fevereiro de 1967 (Código de Mineração). Diário Oficial [da] União: seção 1, Brasília, DF, n. 189, p. 3, 01 out. 2020.

CNRH (Brasil). Rsolução n. 143, de 10 de julho de 2012. Estabelece critérios gerais de classificação de barragens por categoria de risco, dano potencial associado e pelo seu volume, em atendimento ao art. $7^{\circ}$ da Lei ${ }^{\circ} 12.334$, de 20 de setembro de 2010. Diário Oficial [da] União: seção 1, Brasília, DF, 04 set. 2012. 
CAMPINAS. Plano Municipal de Recursos Hídricos. Panorama e Estado dos Recursos Hídricos, volume $1 . \quad$ Campinas, 2016. Available: http://campinas.sp.gov.br/arquivos/meio-ambiente/vol-1-diagnostico.pdf. Access: 12 March 2018.

DAM, T. T.; BURRITT, R. L.; PISANIELLO, J. D. Adequacy of policy and practices for small agricultural dam safety accountability and assurance in Vietnam. Agricultural Water Management, n. 112, p. 63-74, 2012. https://doi.org/10.1016/j.agwat.2012.06.006

ESPAÑA. Ministério de Medio Ambiente. Clasificación de presas en función del riesgo potencial: guía técnica. Madrid:, 1996.

GARCIA, L. do C.; MARTIM, A. L. S. S.; DALFRÉ FILHO, J. G.; FAIS, L. M. C. F. Small Dams Safety Index (SDSI): A reassessment of the parameters of analysis. Engenharia Agrícola Journal, v. 39, p. 715-720, 2019. http://dx.doi.org/10.1590/1809-4430Eng.Agric.v39n6p715-720/2019

HE, K.; PEI, L.; LU, X.; CHEN, J.; WU, Z. Research and Application of Critical Failure Paths Identification Method for Dam Risk Analysis. Mathematical Problems in Engineering, v. 2020, n. 4103804, 2020. https://doi.org/10.1155/2020/4103804

HINTZE, F.; DURO, V.; CARVALHO, J. C.; EIRA, C.; RODRIGUES, P. C.; VINGADA, J. Influence of Reservoirs Created by Small Dams on the Activity of Bats. Acta $\begin{array}{lllllll}\text { Chiropterologica, } & \text { v. } \quad 18, & \text { n. } & 2, & \text { p. } & 395-408,\end{array}$ https://doi.org/10.3161/15081109ACC2016.18.2.007

IPT (SP). Relatório Técnico número 62.317. Convênio DAEE/IPT. São Paulo, 2002.

JING, M.; YANG, J.; LI, S.; WANG, L. Application of fuzzy analytic hierarchy process in the risk assessment of dangerous small-sized reservoirs. International Journal of Machine Learning \& Cybernetics, v. 9, p. 113-123, 2018. https://doi.org/10.1007/s13042-0150363-4

KALININA, A.; SPADA, M.; BURGHERR, P. Application of a Bayesian hierarchical modeling for risk assessment of accidents at hydropower dams. Safety Science, n. 110, p. 164-177, 2018. https://doi.org/10.1016/j.ssci.2018.08.006, 2018.

LI, Z.; WANG, T.; GE, W.; WEI, D.; LI, H. Risk Analysis of Earth-Rock Dam Breach Based on Dynamic Bayesian Network. Water, v. 11, n. 2305, 2019. https://doi.org/10.3390/w11112305

LIMA, D. A.; PINTO, W. L. H.; FAIS, L. M. C. F. Important Aspects in the Safety Assessment of the Small Earth Dams. In: INTERNATIONAL DAM WORLD CONFERENCE, 4. 21-25 Sep. 2020, Lisbon. Proceedings[...] Lisbon: LNEC, 2020. v. 1, p. 57-69.

LIMA, D. A.; COSTA e SILVA, D. C. da; FREIRIA, R. C.; FAIS, L. M. C. F. An overview of the small dams existing in the municipality of Campinas/SP. In: BRAZILIAN SYMPOSIUM OF HYDRICAL RESSOURCES, 24., November, $21^{\text {th }}$ to $26^{\text {th }}$, 2021, Belo Horizonte. Works[...] São Paulo: ABRH, 2021.

LUCCAS, M. L.; SILVA, D. C. C.; FILHO, J. G. D.; FREIRIA, R. C., FAIS, L. M. C. F. A Comparative analysis on regulatory frameworks for small dams. In: INTERNATIONAL DAM WORLD CONFERENCE, 4., 21-25 Sep. 2020, Lisbon. Proceedings[...] Lisbon: LNEC, 2020. v. 1, p. 311-325. 
MELO, J. F. Simplified "Dam-Break" flood modeling. In: INTERNATIONAL DAM WORLD CONFERENCE, 2., 2015, Lisbon. Proceedings[...] Lisbon: LNEC, 2015. p. 47-56.

NAVA, F. R.; ISHIHARA, J. H. RAVENA, N.; VILHENA, K. do S. de S. Lack of knowledge or neglect? The contributions of science to mitigating the risks of small Brazilian dams. International Journal of Disaster Risk Reduction, n. 60, 2021. https://doi.org/10.1016/j.ijdrr.2021.102269

PACHECO, A. P.; HENRIQUES, R. F. F.; RIBEIRO, P. M. V. Technical and scientific aspects of dams in Brazil: a theoretical approach. Revista Ambiente \& Água, v. 15, n. 5, 2020. https://doi.org/10.4136/ambi-agua.2552

PETRY, A., BOMFIM, M., LAUS, F., ANDERAOS, A. Classification of dams by its hazard potential: the experience of the Brazilian National Water Agency. In: INTERNATIONAL DAM WORLD CONFERENCE, 3., 17-21 Sep. 2018, Foz do Iguaçú. Proceedings[...] Lisbon: LNEC, 2018.

PIMENTA, L.; CALDEIRA, L.; DAS NEVES, E. M. A new qualitative method for the condition assessment of earth and rockfill dams. Structure and Infrastructure $\begin{array}{lllllll}\text { Engineering, } & \text { v. } & 9 & \text { n. } & 11, & \text { p. }\end{array}$ https://doi.org/10.1080/15732479.2012.667418

PISANIELLO, J. D.; DAM, T. T., TINGEY-HOLYOAK, J. L. International small dam safety assurance policy benchmarks to avoid dam failure flood disasters in developing countries.

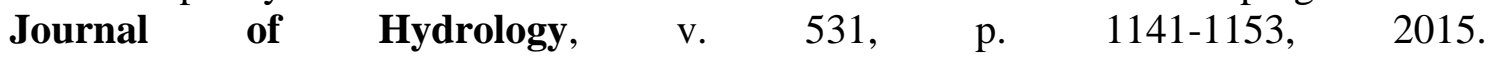
https://doi.org/10.1016/j.jhydrol.2015.09.077

PISANIELLO, J. D.; BURRITT, R. L.; TINGEY-HOLYOAK, J. L. Dam safety management for sustainable farming businesses and catchments. Agricultural Water Management, n. 98, p. 507-516, 2011. https://doi.org/10.1016/j.agwat.2010.10.001

ŘÍHA. J.; KOTAŠKA, S.; PETRULA, L. Dam Break Modeling in a Cascade of Small Earthen Dams: Case Study of the Čižina River in the Czech Republic. Water, v. 12, 2309, 2020. https://doi.org/10.3390/w12082309

SCHAEFER, M.; BARKER, B. Dam Break Inundation Analysis and Downstream Hazard Classification. Dam Safety Guidelines - Technical Note 1. Washington: MGS Engineering Consultants, 2007. Publication Number 92-55E

SUN, R.; ZHOU, Z.; AO, X.; SUN, X.; SONGET, M. Study of the comprehensive risk analysis of dam-break flooding based on the numerical simulation of flood routing. Part I: model development. Natural Hazards, v. 73, n. 3, p. 1547-1568, 2014. https://doi.org/10.1007/s11069-014-1154-Z

WORLD BANK. Contract 051/ANA/2012. Brasília, 2014.

ZHENG, X.; GU, C.; QIN, D. Dam's risk identification under interval-valued intuitionistic fuzzy environment. Civil Engineering and Environmental Systems, v. 32, n. 4, p. 351363, 2015. http://dx.doi.org/10.1080/10286608.2015.1046052

ZHOU, X.; ZHOU, J.; DU, X.; LI, S. Study on dam risk classification in China. Water Science \& Technology: Water Supply, v. 15, n. 3, p. 483-489, 2015. https://doi.org/10.2166/ws.2014.133 


\section{SUPPLEMENTARY MATERIAL}

Table 2. Classification of Associated Potential Damage (DPA).

\begin{tabular}{|c|c|c|c|}
\hline \multicolumn{4}{|c|}{ Classification of Associated Potential Damage - DPA (Water Accumulation) } \\
\hline $\begin{array}{l}\text { Total Reservoir } \\
\text { Volume (a) }\end{array}$ & $\begin{array}{l}\text { Potential for loss of human } \\
\text { life (b) }\end{array}$ & Environmental Impact (c) & Socio Economic Impact (d) \\
\hline $\begin{array}{l}\text { Small } \leq=5 \\
\text { million } \mathrm{m}^{3}(1)\end{array}$ & $\begin{array}{l}\text { NONEXISTENT } \\
\text { (There are no } \\
\text { permanent/resident or } \\
\text { temporary/transiting people } \\
\text { in the affected area } \\
\text { downstream of the dam) } \\
\text { (0) }\end{array}$ & $\begin{array}{l}\text { SIGNIFICANT } \\
\text { (Affected area of the dam } \\
\text { does not represent an area } \\
\text { of environmental interest, } \\
\text { areas protected in specific } \\
\text { legislation or is totally } \\
\text { deprived of its natural } \\
\text { conditions) (3) }\end{array}$ & $\begin{array}{l}\text { NONEXISTENT } \\
\text { (There are no navigation } \\
\text { facilities and services in the } \\
\text { area affected by the dam } \\
\text { accident) (0) }\end{array}$ \\
\hline $\begin{array}{l}\text { Medium } 5 \\
\text { million to } 75 \\
\text { million } \mathrm{m}^{3}(2)\end{array}$ & $\begin{array}{l}\text { LESS COMMON } \\
\text { (There are no people } \\
\text { permanently occupying the } \\
\text { affected area downstream of } \\
\text { the dam, but there is a side } \\
\text { road for local use) (4) }\end{array}$ & $\begin{array}{l}\text { VERY SIGNIFICANT } \\
\text { (Affected area of the dam } \\
\text { has relevant } \\
\text { environmental interest or } \\
\text { is protected in specific } \\
\text { legislation) (5) }\end{array}$ & $\begin{array}{l}\text { LOW } \\
\text { (There is a small } \\
\text { concentration of residential } \\
\text { and commercial, } \\
\text { agricultural, industrial or } \\
\text { infrastructure facilities in the } \\
\text { affected area of the dam or } \\
\text { port facilities or navigation } \\
\text { services) (4) }\end{array}$ \\
\hline $\begin{array}{l}\text { Large } 75 \\
\text { million to } 200 \\
\text { million } \mathrm{m}^{3}(3)\end{array}$ & $\begin{array}{l}\text { FREQUENT } \\
\text { (There are no people } \\
\text { permanently occupying the } \\
\text { affected area downstream of } \\
\text { the dam, but there is a } \\
\text { municipal, state, federal or } \\
\text { other local road and/or } \\
\text { enterprise for the eventual } \\
\text { permanence of people who } \\
\text { could be affected) (8) }\end{array}$ & & $\begin{array}{l}\text { HIGH } \\
\text { (There is a large } \\
\text { concentration of residential } \\
\text { and commercial agricultural, } \\
\text { industrial, infrastructure and } \\
\text { leisure and tourism services } \\
\text { in the affected area of the } \\
\text { dam or port facilities or } \\
\text { navigation services) (8) }\end{array}$ \\
\hline $\begin{array}{l}\text { Very Large > } \\
200 \text { million } \mathrm{m}^{3} \\
\text { (5) }\end{array}$ & $\begin{array}{l}\text { EXISTING } \\
\text { (There are people } \\
\text { permanently occupying the } \\
\text { affected area downstream of } \\
\text { the dam, therefore, human } \\
\text { lives could be harmed) (12) }\end{array}$ & & \\
\hline $\mathrm{APD}=$ & & & \\
\hline
\end{tabular}

Source: CNRH (2012). 